\title{
COVID-19 and Renal Artery Thrombosis: A Case Report
}

\section{COVID-19 ve Renal Arter Trombozu: Olgu Sunumu}

Recai Ergün', Dilek Ergün', Hacer Sürer Shalabi', Mahmoud Yousef Shalabi', Fikret Kanat', Baykal Tulek', Burcu Yormaz', Alaaddin Nayman²

\section{Abstract}

Since the onset of the COVID-19 pandemic, there is increasing evidence that infected patients exhibit a high incidence of thrombotic complications. Although respiratory symptoms are dominant in COVID-19, those with the condition may have extrapulmonary involvement.

Key words: COVID-19, Renal Artery Thrombosis.

\section{Özet}

COVID-19 pandemisinin başlangıcından bu yana, artan kanıtlar, enfekte hastaların yüksek bir trombotik komplikasyon insidansı sergilediğini göstermektedir. Covid-19' da solunum semptomları baskın olsa da, COVID-19' lu hastalarda ekstrapulmoner tutulum da olabilir.

Anahtar Sözcükler: COVID-19, Renal Arter Trombozu.
'Department of Pulmonary Medicine, Selçuk University, Faculty of Medicine, Konya, Turkey

${ }^{2}$ Department of Radiology, Selçuk University, Faculty of Medicine, Konya, Turkey
'Selçuk Üniversitesi Tıp Fakültesi, Göğüs Hastalıkları Anabilim Dalı, Konya

${ }^{2}$ Selçuk Üniversitesi Tıp Fakültesi, Radyoloji Anabilim Dalı, Konya

Submitted (Başvuru tarihi): 28.07.2021 Accepted (Kabul tarihi): 11.10.2021

Correspondence (iletişim): Recai Ergün, Department of Pulmonary Medicine, Selçuk University, Faculty of Medicine, Konya, Turkey

e-mail: recaiergun@gmail.com 
The novel coronavirus disease (COVID-19) is a serious, life-threatening disease that first appeared in Wuhan, China, and the can present with high fever and shortness of breath. Due to its global reach, it was defined as a pandemic on March 11, 2020 (1). Although respiratory symptoms are predominant, patients with COVID-19 may also have extrapulmonary involvement. COVID-19 may predispose to both venous and arterial thromboembolic disease due to excessive inflammation, hypoxia, immobilization and disseminated intravascular coagulation (DIC) (2).

$A$ rare condition seen in patients with prothrombotic states is renal artery thrombosis (3). We present here the case of a 48-year-old male patient with a medical history of Chronic Obstructive Pulmonary Disease (COPD), Diabetes Mellitus (DM) and Hyperlipiemia (HPL) who was admitted to hospital with complaints of fever, cough, shortness of breath, and diagnosed with renal artery thrombosis due to COVID-19. We believe this case will contribute to the body of literature of extra-pulmonary involvement due to COVID-19, which has so far been reported in only limited numbers in literature.

\section{CASE}

A 48-year-old male patient who presented with sudden onset of shortness of breath, cough and fever provided a positive COVID-19 Polymerase Chain Reaction (PCR) test, and was started on antiviral (favipravir 2x1600 mg loading, 2x600 mg maintenance) treatment. After no improvement in symptoms was observed, despite the antiviral treatment, he was admitted to our clinic on the 7th day of symptom onset. The patient had a history of COPD, DM and HPL, and of smoking 15 packs/year. The patient was using Gliclazide, Metformin hydrochloride, Fenofibrate and Pitavastatin, which do not constitute a risk factor for thrombosis. Upon admission, the patient was in a good general condition, conscious, cooperative and oriented, and with a blood pressure of 130/ 80 $\mathrm{mmHg}$, heart rate of $85 / \mathrm{min}$, respiratory rate of 15/ min and $95 \%$ pulse oxygen saturation in room air.

Respiratory system and other system examinations were normal, and biochemical and hematological parameters were normal at the time of admission, aside from mild lymphopenia $\left(600 / \mathrm{mm}^{3}\right)$ and high infection markers (CRP: $49.6 \mathrm{mg} / \mathrm{L})$. D-Dimer: $552 \mathrm{ng} / \mathrm{ml}$ and interleukin 6: $28.54 \mathrm{pq} / \mathrm{ml}$ were detected (Table 1). Thoracic Tomography $(\mathrm{CT})$ revealed diffuse peripheral ground-glass areas that were more prominent in the lower lobes of both lungs (Figure 1). The patient, who was clinically and radi- ologically accepted as having COVID-19 pneumonia, was hospitalized and started on methyl prednisolone 80 $\mathrm{mg}$ and Enoxaparin sodium dose $1 \mathrm{mg} / \mathrm{kg} 1 \mathrm{x} 1$ treatment. Nonspecific antibiotic therapy (piperacillin/tazobactam $3 x$ $4.5 \mathrm{~g}$ and moxifloxacin $400 \mathrm{mg} 1 \times 1)$ and immune plasma were administered twice, 48 hours apart, in line with local guidelines. On the sixth day of hospitalization, the patient developed uninterrupted abdominal pain that started as left flank pain and spread throughout the abdomen. There was no change in urination and anuriaoliguria was not defined. An abdominal examination revealed severe diffuse nonspecific abdominal tenderness, no cost-vertebral angle tenderness, no defense and no rebound, and there was no compatibility with acute abdomen.

The patient's laboratory values were urea: $45 \mathrm{mg} / \mathrm{dl}$, creatinine: $0.77 \mathrm{mg} / \mathrm{dl}$, CRP: $12 \mathrm{mg} / \mathrm{L}$ and Procalcitonin: $0.07 \mathrm{ug} / \mathrm{L}$. Abdominal CT Angiography was performed in patient. Large-scale parenchyma was observed in the upper left upper-middle and lower pole, along with regulating areas (Figure 2). Arterial phase images; occlusions in the distal branches of the left renal artery were not noticeable (Figure 3). Other diagnoses suggested thrombosis were excluded in the patient, and the condition was considered as renal artery thrombosis caused by coronavirus disease 2019 (COVID-19).

In consultation with Urology and Cardiovascular Surgery, the dose of Enoxaparin Sodium was increased to $1 \mathrm{mg} / \mathrm{kg}$ $2 \times 1$. No emergency intervention was considered. The patient, who was followed up in the service, was discharged on the 13th day of hospitalization as his complaints had regressed.

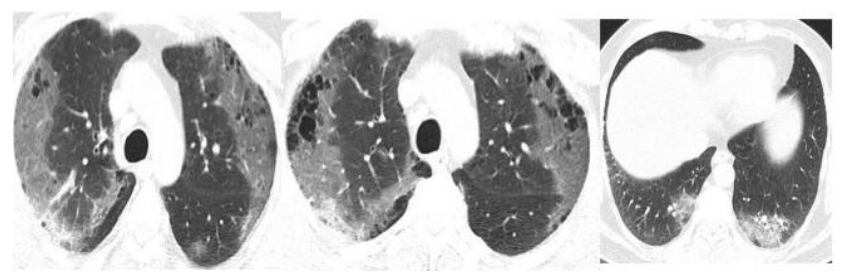

Figure 1: Peripheral ground-glass areas, crazy paving view and cystic appearance in both lungs

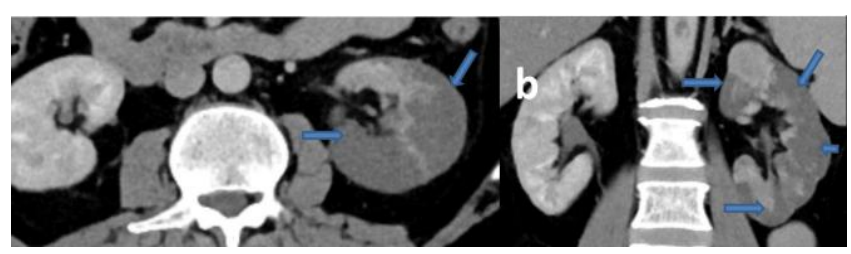

Figure 1: Axial (a) and coronal (b) contrast-enhanced CT images showing the infarct areas in the left kidney (arrows) 


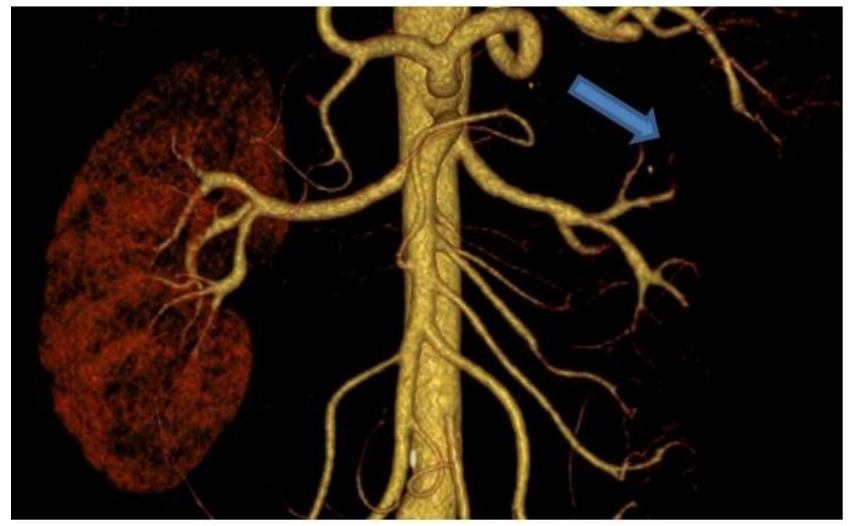

Figure 3: In the segmental arteries of the left kidney, a pruned tree view (arrow) can be seen in the CT angiography image created using the volume rendering technique

\section{DISCUSSION}

As we continue to learn more about the COVID-19 virus and examine the clinical outcomes of infected patients, our knowledge of its complications will improve, allowing us to prepare for their onset. To date, thrombotic complications in patients infected with COVID-19 have been reported, including pulmonary embolism, deep vein thrombosis and catheter-related thrombosis, as well as arterial ischemic strokes (2).

Pulmonary embolism is the most common thrombotic event, while abdominal visceral infarctions have been newly defined (2).

Renal infarction is very rare, with an incidence in the general population of around $0.1-1.4 \%(4)$. It is now known that COVID-19 may predispose patients to thrombotic disease in both venous and arterial circulation due to excessive inflammation, platelet activation, endothelial dysfunction and stasis. This picture has been reported to be caused by the inflammatory storm during and after infection (5). The diagnosis of thrombotic complications, however, is very difficult, and the risk is high, especially in patients followed in the intensive care unit due to COVID19 (2). We present this case due to the rarity of the renal artery thrombosis that developed in our patient with COVID-19 pneumonia as a thrombotic event. Renal artery thrombosis can cause acute symptoms and that can be confused with nephrolithiasis. Our patient had no symptoms other than abdominal pain. Although renal dysfunction and cases requiring dialysis have been reported in literature, renal function was preserved in our case (6). Therefore, in the event of unexplained abdominal pain, even if kidney function is not impaired, abdominal organ infarcts, especially renal arteries, and abdominal arterial thrombosis should be considered.
The detection of acute renal infarction is often delayed or overlooked due to both the rarity of the disease and its nonspecific clinical presentation. Patients with acute renal infarction often present with acute unilateral flank or abdominal pain, suggestive of other more common diseases such as urolithiasis, abdominal disease, lumbago and even myocardial infarction (7). Furthermore, neither risk factors nor laboratory studies with clinically acceptable specificity for acute renal infarction are available. Early imaging (computed tomography or magnetic resonance imaging) facilitates early diagnosis and treatment in patients with high clinical suspicion (7).

Hypercoagulation, when associated with COVID-19, is thought to be associated with widespread endothelial inflammation, increased procoagulant factors such as factor VIII, Von Willebrand factor, fibrinogen and cytokine storm (8). In our patient, the inflammatory markers associated with COVID-19 (fibrinogen: $730 \mathrm{mg} / \mathrm{dL}$, C-reactive protein $125 \mathrm{mg} / \mathrm{L}$, interleukin-6: $28 \mathrm{pg} / \mathrm{mL}$ and procalcitonin: $0.19 \mathrm{ug} / \mathrm{L}, \mathrm{D}$-dimer: $1581 \mathrm{ng} / \mathrm{ml}$, ferritin: 346.1 $\mathrm{ng} / \mathrm{ml}$ ) were elevated, and possibly caused microvascular thrombosis. High fibrinogen levels $(>700 \mathrm{mg} / \mathrm{dL}$ ) make patients more resistant to anticoagulant agents, and have also been shown to increase the risk of thrombosis and decrease the effectiveness of prophylactic dose heparin agents (7). The high fibrinogen levels in our patient support this finding.

This case demonstrates that COVID-19 predisposes patients to hypercoagulation, and suggests that multiple organ failure and death may occur due to thromboembolism. This case contributes to the body of literature on the extrapulmonary complications of COVID-19. Clinicians should consider the possibility of renal infarction development in patients with COVID-19 with complaints of acute abdominal pain. We believe it would be beneficial to raise awareness of the possibility of extrapulmonary thrombosis in patients diagnosed with COVID-19.

The treatment and prevention of thrombotic events in COVID-19 are controversial. The current standard approach is thromboprophylaxis for every hospitalized patient with doses of heparin or LMWH. The average duration of treatment with low molecular weight heparin $(\mathrm{LMWH})$ is 3 weeks. 
Table 1: Laboratory data of the patient

\begin{tabular}{|c|c|c|c|c|c|}
\hline Variable & Admission & $6^{\text {th }}$ Day & $8^{\text {th }}$ Day & Discharge & Reference Range \\
\hline D-Dimer & 552 & 863 & 1581 & 912 & $0-500 \mathrm{ng} / \mathrm{ml}$ \\
\hline Fibrinogen & 565 & 730 & 562 & 425 & $200-400 \mathrm{mg} / \mathrm{dl}$ \\
\hline Urea & 20 & 45 & 46 & 51 & $(17-43 \mathrm{mg} / \mathrm{dl}$ \\
\hline Creatinine & 0.63 & 0.77 & 1.13 & 0.98 & $(0,67-1,17 \mathrm{mg} / \mathrm{dl})$ \\
\hline Ferritin & 231.8 & 297 & 346.1 & 239.9 & $11-306 \mathrm{ng} / \mathrm{ml}$ \\
\hline LDH & & & & & $126-222 \mathrm{mg} / \mathrm{dl}$ \\
\hline IL-6 & 28,54 & & 57,30 & & $0,5-6,4 \mathrm{pg} / \mathrm{ml}$ \\
\hline CRP & 49,6 & 12 & 125 & 9 & $0-8 \mathrm{mg} / \mathrm{l}$ \\
\hline Procalcitonin & 0,05 & 0,07 & 0,19 & 0,06 & $0-0.5 \mathrm{ug} / \mathrm{l}$ \\
\hline Fibrinogen & 565 & 730 & 562 & 425 & $200-400 \mathrm{mg} / \mathrm{dl}$ \\
\hline
\end{tabular}

In conclusion, clinicians should have a low threshold to suspect a diagnosis of thromboembolism/ infarction in the abdominal visceral region if a patient with COVID infection develops abdominal pain.

Further studies are needed to evaluate whether renal infarctions play a role in acute kidney injury (AKI), and whether prophylactic anticoagulation can benefit kidney outcomes.

\section{CONFLICTS OF INTEREST}

None declared.

\section{AUTHOR CONTRIBUTIONS}

Concept - R.E., D.E., H.S.S., M.Y.S., F.K., B.T., B.Y., A.N.; Planning and Design - R.E., D.E., H.S.S., M.Y.S., F.K., B.T., B.Y., A.N.; Supervision - R.E., D.E., H.S.S., M.Y.S., F.K., B.T., B.Y., A.N.; Funding - R.E., D.E., H.S.S., M.Y.S., F.K., B.T., B.Y., A.N.; Materials - R.E., D.E., H.S.S.; Data Collection and/or Processing - F.K., M.Y.S., R.E.; Analysis and/or Interpretation - R.E., D.E., B.T., H.S.S.; Literature Review - R.E., D.E.; Writing - R.E., M.Y.S., H.S.S.; Critical Review - R.E., D.E., F.K.

\section{YAZAR KATKILARI}

Fikir - R.E., D.E., H.S.S., M.Y.S., F.K., B.T., B.Y., A.N.; Tasarım ve Dizayn - R.E., D.E., H.S.S., M.Y.S., F.K., B.T., B.Y., A.N.; Denetleme - R.E., D.E., H.S.S., M.Y.S., F.K., B.T., B.Y., A.N.; Kaynaklar - R.E., D.E., H.S.S., M.Y.S., F.K., B.T., B.Y., A.N.; Malzemeler - R.E., D.E., H.S.S.; Veri Toplama ve/veya İşleme - F.K., M.Y.S., R.E.; Analiz ve/veya Yorum - R.E., D.E., B.T., H.S.S.; Literatür Tara- ması - R.E., D.E.; Yazıyı Yazan - R.E., M.Y.S., H.S.S.; Eleştirel İnceleme - R.E., D.E., F.K.

\section{REFERENCES}

1. Adil MT, Rahman R, Whitelaw D, Jain V, Al-Taan $O$, Rashid $F$, et al. SARS-CoV-2 and the pandemic of COVID-19. Postgrad Med J 2021; 97:1 10-6. [CrossRef]

2. Klok FA, Kruip MJHA, van der Meer NJM, Arbous MS, Gommers DAMPJ, Kant KM, et al. Incidence of thrombotic complications in critically ill ICU patients with COVID19. Thromb Res. 2020; 191:145-7. [CrossRef]

3. El Shamy O, Munoz-Casablanca N, Coca S, Sharma S, Lookstein R, Uribarri J. Bilateral renal artery thrombosis in a patient with COVID-19. Kidney Med 2021; 3:116-9. [CrossRef]

4. Ramanathan M, Chueng T, Fernandez E, GonzalesZamora J. Concomitant renal and splenic infarction as a complication of COVID-19: a case report and literature review. Infez Med 2020; 28:611-5.

5. Deshmukh S, Upadhyay K, Kulkarni A, Deshpande S, Purohit R, Kulkarni M. Renal artery thrombosis: A post COVID-19 sequel. J Adv Res Med 2020; 7:22-4. [CrossRef]

6. Boui M, Hammoune N, Slioui B, Bellasri S, Ben Elhend S, Zouaki Z, et al. Concomitant acute pulmonary embolism, intracardiac thrombus and renal artery thrombosis in COVID-19 patient Thrombosis Update 2021; 3:100042. [CrossRef]

7. Barrett CD, Moore HB, Yaffe MB, Moore EE. ISTH interim guidance on recognition and management of coagulopathy in COVID-19: A comment. J Thromb Haemost 2020; 18:2060-3. [CrossRef] 
8. Singh B, Mechineni A, Kaur P, Aidir N, Maroules M, Shamoon $\mathrm{F}$, et al. Acute intestinal ischemia in a Patient with COVID-19 Infection. Korean J Gastroenterol 2020; 76:164-6. [CrossRef] 